\title{
COVID-19 PATIENTS' SATISFACTION WITH QUALITY OF MEDICAL CARE PROVIDED IN THE FORM OF TELEMEDICINE CONSULTATIONS
}

Polunina NV ${ }^{1}$, Tyazhelnikov $A A^{1,2}$, Pogonin $\mathrm{AV}^{1,3}$, Kostenko EV ${ }^{1,4} \bowtie$

${ }^{1}$ Pirogov Russian National Research Medical University, Moscow, Russia

${ }^{2}$ Consultative and Diagnostic Polyclinic № 121, Moscow, Russia

${ }^{3}$ Spasokukotsky City Clinical Hospital, Moscow, Russia

${ }^{4}$ Moscow Centre for Research and Practice in Medical Rehabilitation, Restorative and Sports Medicine, Moscow, Russia

The paper reports the results of survey carried out in order to assess patients' opinion on the remote medical care provided by the telemedicine center of the Department of health of Moscow during the pandemic. Survey of 216 COVID-19 patients who received outpatient care made it possible to assess their health condition and determine the factors contributing to satisfaction with care provided. Patients' health condition was evaluated based on the course of underlying disease and comorbidities, which were revealed in $24.3 \%$ of COVID-19 patients. The following three groups were formed: patients with favorable (37.5\%), satisfactory (36.7\%) and unfavorable (25.8\%) health condition. The majority of patients $(76.4 \%)$ were satisfied with telemedicine consultations; men (79.8\%), individuals with favorable condition $(83.1 \%)$ and patients under $50(81.9 \%)$ demonstrated significantly higher level of satisfaction. The following arguments in favour of telemedicine consultations were specified by patients: appointment of the specialist's consultation, promptness of treatment appointment, provision of medical recommendations, including recommendations on a healthy lifestyle, as well as promptness of house call and ambulance call. The main dissatisfaction reasons were as follows: lack of appropriate equipment, difficulties when setting up the equipment, complexity of the instructions for connecting to telemedicine consultations, poor quality of video/audio conferencing; these indicated the patients' inadequate technical resources. Telemedicine consultations may be considered an effective method of outpatient care provision for COVID-19 patients, especially since $64.7 \%$ of patients plan to use telemedicine consultations in the future, and $72.3 \%$ of patients are ready to recommend them to others.

Keywords: telemedicine consultations, morbidity, COVID-19, pandemic, satisfaction

Author contribution: Polunina NV, Tyazhelnikov AA, Pogonin AV — study concept and design; Tyazhelnikov AA, Kostenko EV — data acquisition and processing; Polunina NV — statistical analysis; Tyazhelnikov AA, Kostenko EV — manuscript writing; Polunina NV — manuscript editing.

Compliance with ethical standards: the study was approved by the Ethics Committee of the City Policlinic № 2 of the Department of health of Moscow (protocol № 9 dated September 30, 2020). The survey was carried out by consent of the patient under full anonymity; the patient was informed that his/her personal data would never be used anywhere else.

$\triangle$ Correspondence should be addressed: Elena V Kostenko

Zemlyanoy Val, 53, Moscow, 105120; ekostenko58@mail.ru

Received: 27.11.2020 Accepted: 14.12.2020 Published online: 27.12.2020

DOI: $10.24075 /$ brsmu.2020.084

\section{УДОВЛЕТВОРЕННОСТЬ ПАЦИЕНТОВ С COVID-19 КАЧЕСТВОМ МЕДИЦИНСКОЙ ПОМОЩИ, ОКАЗАННОЙ В ФОРМЕ ДИСТАНЦИОННЫХ ТЕЛЕМЕДИЦИНСКИХ КОНСУЛЬТАЦИЙ}

\author{
Н. В. Полунина ${ }^{1}$, А. А. Тяжельников ${ }^{1,2}$, А. В. Погонин ${ }^{1,3}$, Е. В. Костенко ${ }^{1,4} \bowtie$ \\ ${ }^{1}$ Российский национальный исследовательский медицинский университет имени Н. И. Пирогова, Москва, Россия \\ 2 Консультативно-диагностическая поликлиника № 121, Москва, Россия \\ з ГКБ имени С. И. Спасокукоцкого, Москва, Россия \\ ${ }^{4}$ Московский научно-практический центр медицинской реабилитации, восстановительной и спортивной медицины, Москва, Россия
}

В статье представлены результаты исследования мнения пациентов об оказании дистанционной консультативной медицинской помощи в телемедицинском центре ДЗМ в условиях пандемии. Обследование 216 пациентов с COVID-19, находившихся на амбулаторном лечении, дало возможность оценить их здоровье и определить факторы, влияющие на удовлетворенность предоставляемыми услугами. Здоровье пациентов оценивали на основании изучения течения основного заболевания и наличия сопутствующих заболеваний, которые были выявлены у 24,3\% заболевших COVID-19. Были сформированы три группы - с благоприятной (37,5\%), удовлетворительной $(36,7 \%)$ и неблагоприятной (25,8\%) характеристиками здоровья. Большинство пациентов (76,4\%) остались удовлетворены телемедицинскими консультациями, при этом достоверно чаще - мужчины (79,8\%), лица, имеющие благоприятное здоровье (83,1\%), и пациенты моложе 50 лет (81,9\%). В качестве аргументов использования телемедицинских консультаций пациенты указывали получение консультаций специалистов, оперативность назначения лечения, получение медицинских рекомендаций, в том числе по здоровому образу жизни, а также быстроту оформления вызова врача на дом и скорой медицинской помощи. Основными причинами неудовлетворенности были отсутствие у пациентов соответствующего оборудования, трудности с настройкой оборудования, сложность инструкции по подключению к телемедицинским консультациям, неудовлетворительное качество аудио- и видеосвязи, что свидетельствует о недостаточной технической оснащенности пациентов. Телемедицинские консультации могут быть рассмотрены в качестве эффективного метода при амбулаторном лечении пациентов с COVID-19, тем более, что 64,7\% пациентов планируют в будущем их использование, а 72,3\% готовы рекомендовать их другим.

Ключевые слова: телемедицинские консультации, заболеваемость, COVID-19, пандемия, удовлетворенность

Вклад авторов: Полунина Н. В., Тяжельников А. А., Погонин А. В. - концепция и дизайн исследования; Тяжельников А. А., Костенко Е. В. - сбор и обработка материала; Полунина Н. В. - статистическая обработка; Тяжельников А. А., Костенко Е. В. - написание статьи; Полунина Н. В. редактирование.

Соблюдение этических стандартов: исследование одобрено этическим комитетом ГБУЗ «Городская поликлиника № 2 Департамента здравоохранения г. Москвы» (протокол № 9 от 30 сентября 2020 г.). Анкетирование проводили при условии согласия пациента с соблюдением анонимности, информируя пациента о том, что его личные данные нигде не будут использованы.

$\varangle$ Для корреспонденции: Елена Владимировна Костенко ул. Земляной Вал, д. 53, г. Москва, 105120; ekostenko58@mail.ru

Статья получена: 27.11.2020 Статья принята к печати: 14.12.2020 Опубликована онлайн: 27.12.2020

DOI: $10.24075 /$ vrgmu.2020.084 
The epidemic situation of 2020 posed new challenges both for global health care and for domestic health care system. The most important epidemiological aspect during the pandemic is limiting the spread of infection by reducing contacts, including the patient's visits to a polyclinic or home visits by doctors [1].

During the pandemic, the growing people's need in timely and quality medical care resulted in need for implementation of novel information and communication technologies when providing the outpatient care. Remote technologies make it possible not only to expand access to medical services, but also to reduce the risk of the novel coronavirus infection COVID-19 spread, allowing the patients not to violate the self-isolation regime and not to expose others to the risk of infection. According to the Moscow Operational Headquarters for preventing the spread of coronavirus infection data of March 29, 2020, on average, 62\% of patients infected with SARS-CoV-2 have mild or asymptomatic disease. Despite the fact that the disease is more often mild, such patients require medical supervision, however, if they need medical care, this allows physicians to follow-up this group of patients on an outpatient basis.

Remote technologies, which include tele-health [2], make it possible to provide the patient with high-quality and affordable medical care, regardless of the location of the physician, ensuring epidemiological safety of both healthcare specialists and the patient. Telemedicine development trends demonstrate the relevance of studying the opinions of patients about the implementation of telemedicine consultations, which is necessary for the development of proposals for improvement of those [3].

In this paper, the experience of remote medical care (telemedicine consultations) provision is reported, and the assessment of patients' satisfaction with quality of such consultations is presented.

Patients' satisfaction is one of the medical care quality indicators recognized both in the Russian Federation and other countries. Patient's satisfaction with the quality of services results from comparison of patient's expectations and the actual experience associated the use of the service. Thus, the level of satisfaction and subjective assessment of the service quality directly correlates with expectations and requirement not necessarily stated in administrative regulations and other regulations governing the provision of certain services [4, 5].

Due to growing abundance of digital and telemedicine technologies in the system of medical care provision, it is important to study the key indicator characterizing the quality of the health care system, i. e. the patient's satisfaction and the factors contributing to patient's satisfaction [6-8].

Monitoring of patients' opinions is required to ensure flexibility in improving new technologies in accordance with the patients' basic needs when integrating telemedicine technologies into the health care system. Since satisfaction with medical care consists of many factors, which are most often subjective [9], surveys were recognized as the most informative method for studying the patients' opinion about the work of the health care system [10]. The development of telemedicine technologies contributes to availability of outpatient care, regardless of the patient's condition and location [11].
The study was aimed to assess the patients' satisfaction with quality of medical care provided in the form of telemedicine consultations.

\section{METHODS}

The study was carried out in the Telemedicine Centre of the Department of health of Moscow (TMC DHM) organized in the Consultative and Diagnostic Polyclinic no. 121. Inclusion criteria: documentary evidence of COVID-19 diagnosis, outpatient treatment.

In order to assess the patients' perception in relation to satisfaction with medical care provided and quality of remote consultation, the 216 patients' survey was carried out using the specially developed "Questionnaire for Assessment of COVID-19 Patients' Satisfaction with Quality of Care Provided by the Telemedicine Center". The answers were ranked using the 5-point scale. When compiling the questionnaire, we used verification questions, which made it possible to exclude incorrectly completed forms (see Appendix). The survey was carried out from April 30 to May 10, 2020 by the Telemedicine Center administrator, who interviewed the patients with confirmed COVID-19 diagnosis, who had received telemedicine consultations, by phone and filled the form.

Morbidity was studied using information about the symptoms of the underlying disease and chronic diseases in patients with COVID-19 copied from the "Medical record of a patient receiving medical care on an outpatient basis". These data was entered in a sample card, which also contained patient's full name, date of birth, place of residence, date of consultation and results of remote health monitoring.

Statistical analysis performed with the IBM SPSS Statistics software for Windows, version 20.0 (IBM Corp.; USA), included the following: calculation of extensive and intensive indicators, calculation of mean and the error of the mean, assessment of significance, comparison of mean values and indicators. The differences are considered significant when $P \geq 0.95$.

\section{RESULTS}

The data obtained indicate that almost every $3^{\text {rd }}$ patient was aged $30-40(32.7 \%)$, every $4^{\text {th }}$ was aged $40-50(23.1 \%)$, and every 5 th was aged 50-60 (19.4\%). The smallest groups included patients aged 20-29 (15.6\%) and 60+ (9.2\%).

The average age of surveyed patients was $40.3 \pm 0.72$ in men, and in women the average age was significantly higher $(44.2 \pm 0.97, P<0.01)$. It was shown that among men $40.4 \%$ of patients were aged $30-40$, and the proportion of women was $26.6 \%(P \leq 0.05)$. Among women, the patients aged $40-50$ predominated (27.3\%), and the proportion of men in this age group was $15.7 \%(P \leq 0.05)$. The smallest number of both men and women were aged 20-29 (20.2\% and $12.5 \%$ respectively, $P \geq 0.05)$ and $60+(10.1 \%$ and $10.2 \%$ respectively, $P \geq 0.05$ ).

Significant gender differences were observed in all age groups except two: under 30 and 60+.

Table 1. Distribution of male and female COVID-19 patients based on the symptoms reported (\% of the total number)

\begin{tabular}{|l|c|c|c|}
\hline \multicolumn{1}{|c|}{$\begin{array}{c}\text { Number of symptoms in patients } \\
\text { with COVID-19 }\end{array}$} & Men & Women & Forecasting probability, $P$ \\
\hline 0-3 symptoms & 44.9 & 29.9 & $\geq 0.99$ \\
\hline 4-7 symptoms & 30.3 & 43.3 & $\geq 0.95$ \\
\hline 8-12 symptoms & 24.7 & 26.8 & $\leq 0.95$ \\
\hline Total & 100.0 & 100.0 & \\
\hline
\end{tabular}


Table 2. Ranked distribution of disorders by classes in surveyed COVID-19 patients (\% of the total number)

\begin{tabular}{|c|c|c|c|c|}
\hline \multirow{2}{*}{ Rank } & \multicolumn{2}{|c|}{ Men } & \multicolumn{2}{|c|}{ Women } \\
\cline { 2 - 5 } & Classes of disorders & $\%$ & Classes of disorders & 19.1 \\
\hline 1 & Circulatory system diseases & 14.8 & Circulatory system diseases & 13.1 \\
\hline 2 & Digestive diseases & 11.8 & Digestive diseases & 11.3 \\
\hline 3 & Musculoskeletal system diseases & 10.9 & Musculoskeletal system diseases & 9.5 \\
\hline 4 & Neoplasms & 10.7 & Neoplasms & 8.7 \\
\hline 5. & Urogenital disorders & 10.6 & Urogenital disorders & 7.8 \\
\hline 6 & Respiratory disorders & 10.2 & Respiratory disorders & 7.6 \\
\hline 7 & Disorders of eye and adnexa & 6.8 & Disorders of eye and adnexa & 22.9 \\
\hline & Other & 24.2 & Other & 100 \\
\hline
\end{tabular}

Analysis of the health condition performed based on the medical records included the assessment of both underlying disease course and comorbidities. The data obtained showed that in most surveyed patients who received outpatient care the mild course of COVID-19 was observed, and patients with severe course of the disease were hospitalized to appropriate hospitals.

However, the patients with mild course of the disease may have various symptoms. The study of the prevalence rate of the disorder showed that most COVID-19 patients who received outpatient treatment complained of elevated body temperature (84.9 cases per 100 surveyed patients), dry or minimally productive cough (74.3 cases per 100 surveyed patients), shortness of breath (48.5 cases per 100 surveyed patients), weakness (78.6 cases per 100 surveyed patients), fatigue (69.2 cases per 100 surveyed patients), loss of smell (37.5 cases per 100 surveyed patients), conjunctivitis (29.7 cases per 100 surveyed patients), and sleep disturbances (61.8 cases per 100 surveyed patients). Headache (14.3 cases per 100 surveyed patients), nausea and vomiting (9.6 cases per 100 surveyed patients), and diarrhea (7.3 cases per 100 surveyed patients) were the least prevalent symptoms.

It was noted that one patient experienced an average of $5.39 \pm 0.09$ symptoms. The patients were divided into three groups based on the number of symptoms. The first group included patients with favorable health conditions who reported no complaints or up to three complaints. The proportion of such patients was $37.5 \%$. The third group included patients with unfavorable health conditions who reported 8 or more complaints; the proportion of such patients was $25.7 \%$. Other patients comprised the second group; their proportion was $36.8 \%$.

The data obtained showed that patients with more favorable course of the disease predominated among men, and patients who reported 4-7 symptoms predominated among women (Table 1). At the same time, the proportion of patients who reported 8 or more symptoms was $24.7 \%$ in men and $26.8 \%$ in women.

The study of comorbidities in patients with COVID-19 was performed due to several reasons. First, comorbidities may worsen the course of COVID-19 and lead to disability. Second, comorbid patients require extra medical supervision and extra medication.

The in-depth study of the supervised COVID-19 patients' health conditions indicated that $24.3 \%$ of the infected patients were comorbid. Comorbidities were detected in $14.7 \%$ of men, and among women the proportion of comorbid patients was significantly (by 2.3 times, $P<0.01$ ) higher (33.9\%). The comorbidity rate was $350.2 \%$, among them in patients under 40 it was $312.9 \%$, and among patients $40+$ it was $387.8 \%$. The morbidity rate analysis in men and women showed that the morbidity rate was significantly (by 1.4 times, $P<0.99$ ) in men compared to women (290.8\% and $409.7 \%$ respectively).

In the structure of comorbidity the first seven places belonged to circulatory system diseases (17.3\%), urogenital disorders (12.1\%), musculoskeletal system diseases (11.2\%), digestive diseases (10.5\%), neoplasms (9.5\%), respiratory disorders (8.7\%), disorders of eye and adnexa (7.4\%). The proportion of those was $76.7 \%$ of the total number of detected comorbidities.

It was found that the majority of the disorders, revealed in surveyed male and female patients $(75.8 \%$ and $77.1 \%$ respectively), was comprised by the listed classes of disorders. However, the ranked distribution of morbidity was different (Table 2).

Despite the fact that the first place in the structure of comorbidities in COVID-19 patients belonged to circulatory system diseases, the morbidity rate for this class of disorders was 1.8 times higher in women than in men $(78.1 \%$ and $43.1 \%$ respectively). The morbidity rate was higher in women compared to men for almost all classes of disorders; the most significant differences in the prevalence rate were observed for urogenital disorders (by 1.7 times - 53.8\% and 30.9\% respectively), disorders of eye and adnexa (by 1.6 times $31.9 \%$ and $19.8 \%$ respectively), and musculoskeletal system diseases (by 1.4 times - $46.1 \%$ and $31.8 \%$ respectively).

Worth noting is the relationship between comorbidities and the number of symptoms reported (Table 3). Among patients with no comorbidities, the number of individuals who reported no more than three symptoms was significantly higher (by 2.1 times, $P \geq 0.95$ ), and the number of individuals who reported 8 and more symptoms was significantly lower (by 1.7 times, $P \geq 0.95)$.

Table 3. Distribution of COVID-19 based on the number of complaints and reported comorbidities ((\% of the total number)

\begin{tabular}{|l|c|c|c|}
\hline \multicolumn{1}{|c|}{$\begin{array}{c}\text { Number of symptoms in patients } \\
\text { with COVID-19 }\end{array}$} & Patients with no comorbidities & Comorbid patients & 26.5 \\
\hline 0-3 symptoms & 49.6 & 39.4 & $\geq 0.99$ \\
\hline 4-7 symptoms & 30.8 & 34.1 & $\leq .95$ \\
\hline 8-12 symptoms & 19.6 & 100.0 & $\geq 0.95$ \\
\hline Total & 100.0 & & \\
\hline
\end{tabular}




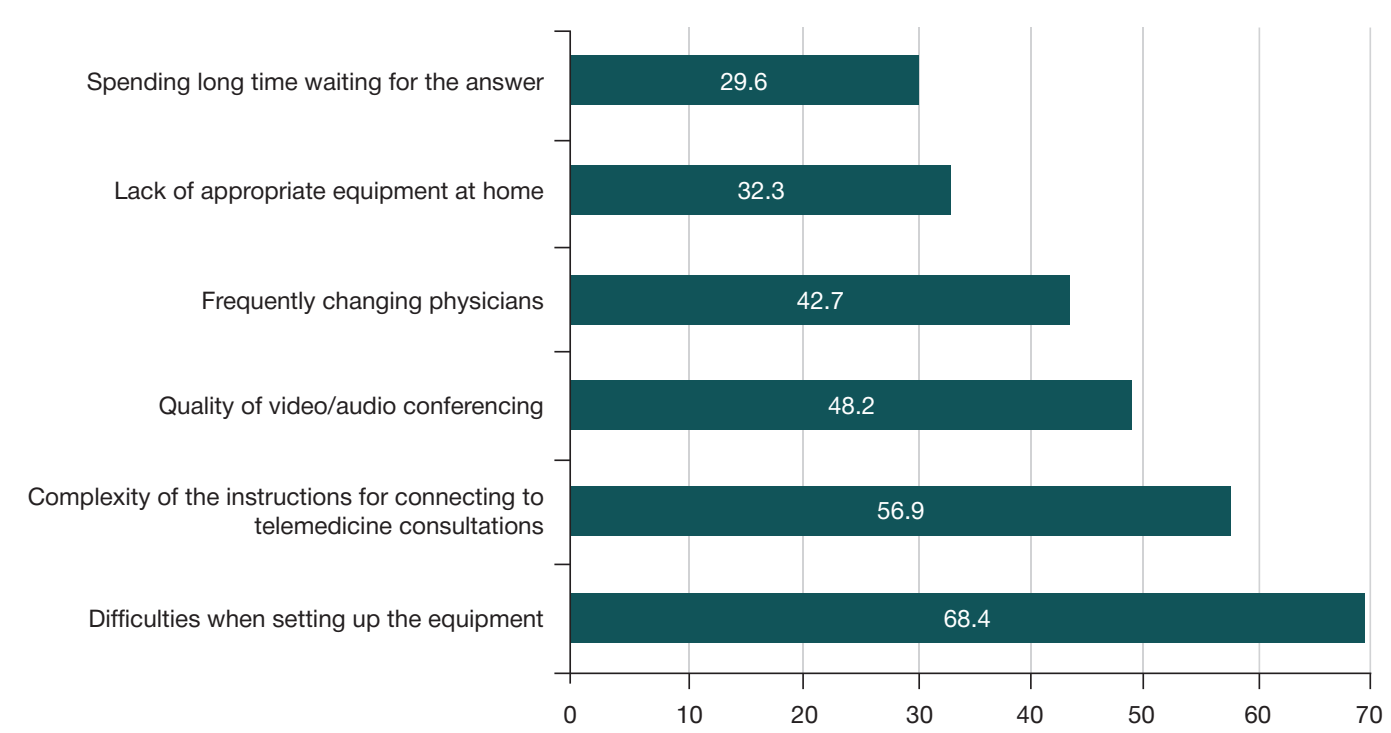

Fig. 1. Frequency of COVID-19 patients based on the reasons for dissatisfaction with telemedicine consultations (per 100 surveyed patients)

The data show that unfavorable course of the disease is more common in comorbid patients.

A specialized telemedicine center was created for patients with COVID-19, the main task of which was to provide online consultations for patients with a confirmed diagnosis of coronavirus infection. Since the patients' condition allowed for outpatient treatment, such patients were provided with remote telemedicine consultations from specially equipped telemedicine center.

The online consultations were 24-hour. The use of video monitoring together with audio/video conferencing makes it possible to assess the patient's condition, the use of electronic patient records and other data from UMIAS makes it possible to assess the course of the disease, and the data on comorbidities allow the physicians to adjust treatment. During the consultations the physicians provide medical recommendations and answer the patient's questions.

The data indicated that the majority of surveyed COVID-19 patients (76.4\%) were satisfied with telemedicine consultations. It was found that among patients satisfied with telemedicine consultations there were significantly $(P<0.95)$ more men than women $(79.8 \%$ in the group of men and $68.5 \%$ in the group of women).

It was noted that the level of satisfaction with telemedicine consultations was higher in patients with no comorbidities who reported no more that 3 symptoms of the disease compared to patients classified as patients with unfavorable health condition (83.1\% vs. 62.1\%, $P<0.95$ ).

The main arguments in favour of remote consultations reported by patients were as follows: appointment of the specialist's consultation (73.9\% of patients), promptness of care appointment (61.6\% of patients), provision of recommendations for a healthy lifestyle (52.8\% of patients) and medical recommendations (47.3\% of patients), promptness of laboratory tests' results (49.2\% of patients), continuous health monitoring (39.6\% of patients), as well as promptness of house call (31.7\% of patients) and ambulance call (29.3\% of patients).

It was noted that men more often specified such arguments in favour of contacting the telemedicine center as promptness of care appointment and provision of medical recommendations, and women more often specified such arguments as appointment of the specialist's consultation, continuous health monitoring and promptness of house call. An average of 3-4 in favour of remote consultations per COVID-19 patient was noted: the average number of arguments in male patients was $3.1 \pm 0.21$, and in female patients it was $4.6 \pm 0.36(P<0.99)$.

Analysis of reasons for dissatisfaction with remote care quality showed that the leading place belonged to technical problems, such as lack of appropriate equipment, difficulties when setting up the equipment, complexity of the instructions for connecting to telemedicine consultations, quality of video/ audio conferencing, frequently changing physicians, spending long time waiting for the answer (Fig. 1).

It was found that patients of older age were more sensitive to the quality of medical care, including the remote care. Generally, it was noted that the significantly higher (by 1.7 times) proportion of patients over 40 compared to patients under 40 was dissatisfied with provided remote medical care $(29.7 \%$ vs. $17.5 \%$ respectively).

Table 4. Frequency of COVID-19 patients based on the reasons for dissatisfaction with telemedicine consultations and age (per 100 surveyed patients)

\begin{tabular}{|c|c|c|c|c|}
\hline \multirow{2}{*}{ п/№ } & \multirow{2}{*}{ Dissatisfaction reasons } & \multicolumn{2}{|c|}{ Number of cases per 100 surveyed patients } & \multirow{2}{*}{ Forecasting probability, $P$} \\
\hline & & Under 50 & Over 50 & \\
\hline 1 & Difficulties when setting up the equipment & 53.2 & 73.6 & $\geq 0.99$ \\
\hline 2 & $\begin{array}{l}\text { Complexity of the instructions for connecting to } \\
\text { telemedicine consultations }\end{array}$ & 44.5 & 61.3 & $\geq 0.95$ \\
\hline 3 & Quality of video/audio conferencing & 39.3 & 57.1 & $\geq 0.95$ \\
\hline 4 & Frequently changing physicians & 32.6 & 46.8 & $\leq 0.95$ \\
\hline 5 & Lack of appropriate equipment at home & 21.3 & 43.2 & $\geq 0.99$ \\
\hline 6 & Spending long time waiting for the answer & 30.5 & 18.7 & $\geq 0.95$ \\
\hline 7 & Lack of timeliness & 27.3 & 15.3 & $\geq 0.95$ \\
\hline 8 & Lack of information completeness & 14.6 & 19.2 & $\leq 0.95$ \\
\hline
\end{tabular}




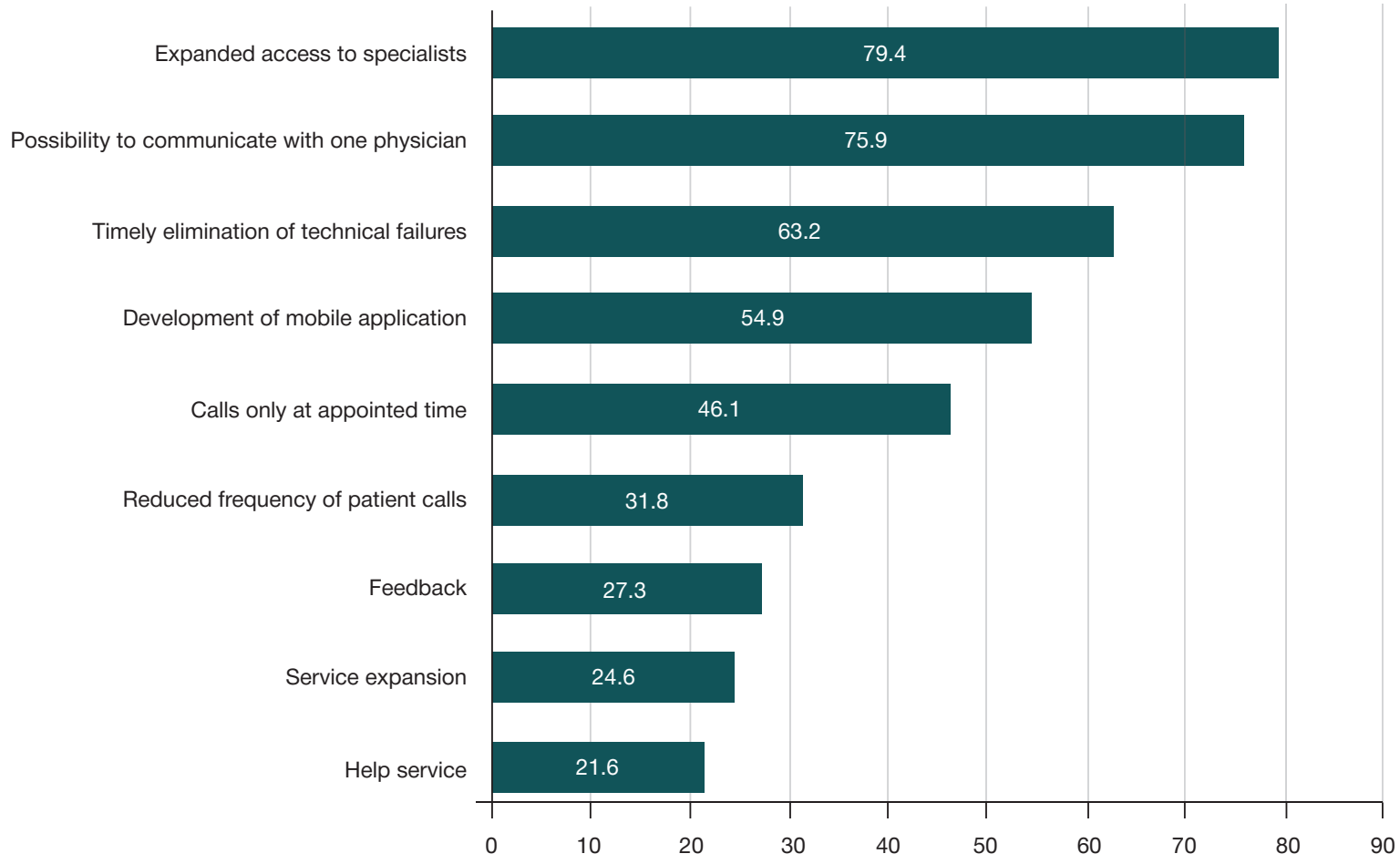

Fig. 2. Distribution of COVID-19 based on the proposals concerning the telemedicine consultation quality improvement (per 100 surveyed patients)

Compared to younger patients, patients aged 40+ (Table 4) more often have no equipment for remote communication, they more often experience difficulties when setting up the equipment and poor communication quality.

One of the criteria of satisfaction with medical care quality is timeliness and completeness of providing the patient with health data. It has been found that the patients of older age tend to be more patient. They less often specified spending long time waiting for the answer and lack of timeliness in provision of consultations as the reasons of dissatisfaction compared to younger patients.

\section{DISCUSSION}

Analysis of answers showed that the answers about the lack of information completeness were mainly concerning situations not related to medical care characterized by organizational or legal orientation. The patients paid special attention to evaluation of the communication quality, since visual assessment of the patient's condition was one of the most important tasks of telemedicine consultations. At the same time, the physicians communicated with the patients via audio conferencing in every $5^{\text {th }}$ case $(19.2 \%)$, in $18.1 \%$ they used audio/video conferencing, and in $14.5 \%$ they used video conferencing.

Unfortunately, every second patient reported poor quality of video conferencing, which contributed to dissatisfaction with telemedicine consultations (48.2\%). Among patients of older age, significantly more (by 1.4 times) people experienced problems with video conferencing compared to younger patients (57.1\% vs. 39.3\%, $P \leq 0.95)$.

Thestudy of patients' proposals concerning the improvement of telemedicine is an important aspect of the outpatient medical center medical and organizational performance (Fig. 2).

The most frequent proposals were as follows: expanded access to specialists, possibility to communicate with one physician, and timely elimination of technical failures. In addition to the patients' satisfaction with the telemedicine center activities survey results, the quality of telemedicine consultations can be judged based on the patients' desire to use this medical care type of in the future, as well as to recommend it to their friends and acquaintances. The data obtained has shown that $64.7 \%$ of surveyed COVID-19 patients plan using the telemedicine consultations in the future, and $72.3 \%$ of patients are willing to recommend it to others.

Despite the subjectivity component, the indicator of patient satisfaction with medical care is highly informative and can be used not only to assess the quality of telemedicine consultations, but also to develop measures for medical care improvement.

\section{CONCLUSION}

1. Implementation of remote telemedicine consulting into management of patients with confirmed COVID-19 makes it possible to assess patient's health condition, to perform the dynamic monitoring of the course of the disease and ensure timely treatment adjustment. 2. The indicator of patients' satisfaction with quality of medical care received is subjective and associate with patients' health condition. Thus, the level of satisfaction with telemedicine consultations was higher in patients who reported no COVID-19 symptoms or no more than 3 symptoms compared to patients classified as the group with unfavorable health condition. 3. Among reasons for dissatisfaction with remote medical care the leading place belongs to technical problems and organizational aspects; this served as the basis for development of measures required for this medical care type improvement. 4. The main directions of the telemedicine services quality improvement are as follows: improvement of technical requirements for equipment, taking into account the elimination of causes leading to failures during telemedicine consultations; provision of patients with mobile applications for telemedicine consultations; expanded access to specialists in accordance with comorbidity revealed in patient with COVID-19; remote consultations provided by the same physician throughout the follow-up period. 5. Taking into account the fact that $64.7 \%$ of surveyed COVID-19 patients plan to use telemedicine consultations in the future, and 
$72.3 \%$ of patients are ready to recommend them to others, implementation of remote medical services as the new form of quality medical care provision by outpatient centers and the expansion of those using the information and communication technologies should be considered. This is one of the promising areas of modern healthcare.

\section{References}

1. Matias T, Dominski FH, Marks DF. Human needs in COVID-19 isolation. J Health Psychol. 2020; 25 (7): 871-82. DOI: 10.1177/1359105320925149

2. Prikaz Minzdrava RF ot 30.11.2017 №965 «Ob utverzhdenii poryadka organizacii i okazaniya medicinskoj pomoshchi s primeneniem telemedicinskih tekhnologij». Russian.

3. Akulin IM, Chesnokova EA, Presnyakov SA, Pryadko AE, Zimina El, Guryanova NE. Poryadok osushchestvleniya telemedicinskih konsul'tacij $v$ sub"ektah Rossijskoj Federacii. Vrach i informacionnye tekhnologii. 2020; №3: 45-59. DOI: 10.37690/1811-0193-2020-3-49-59. Russian.

4. Bojkov VE, Dobrolyubova El, Zybunovskaya NV, Pokida AN. Rezul'taty issledovaniya obshchej udovletvorennosti grazhdan kachestvom gosudarstvennyh i municipal'nyh uslug. Sociologiya vlasti. 2012; 1: 40-65. Russian.

5. Prikaz Ministerstva zdravoohraneniya RF ot 10 maya 2017 g. № 203n «Ob utverzhdenii kriteriev ocenki kachestva medicinskoj pomoshchi». Russian.

6. Jacobs JJ, Ekkelboom R, Jacobs JP, et al. Patient satisfaction with a teleradiology service in general practice. BMC Fam Pract. 2016; Feb 10; 17: 17. DOI: 10.1186/s12875-016-0418-y.

7. Morozov SP, Vladzimirskij AV, Simenyura SS. Kachestvo pervichnyh

\section{Литература}

1. Matias T, Dominski FH, Marks DF. Human needs in COVID-19 isolation. J Health Psychol. 2020; 25 (7): 871-82. DOl: 10.1177/1359105320925149.

2. Приказ Минздрава РФ от 30.11.2017 № 965 «Об утверждении порядка организации и оказания медицинской помощи с применением телемедицинских технологий».

3. Акулин И. М., Чеснокова Е. А., Пресняков С. А., Прядко А. Е., Зимина Е. И., Гурьянова Н. Е. Порядок осуществления телемедицинских консультаций в субъектах Российской Федерации. Врач и информационные технологии. 2020; 3: 45-59. DOI: 10.37690/1811-0193-2020-3-49-59.

4. Бойков В. Э., Добролюбова Е. И., Зыбуновская Н. В., Покида А. Н. Результаты исследования общей удовлетворенности граждан качеством государственных и муниципальных услуг. Социология власти. 2012; 1: 40-65.

5. Приказ Министерства здравоохранения РФ от 10 мая 2017 г. № 203н «Об утверждении критериев оценки качества медицинской помощи».

6. Jacobs JJ, Ekkelboom R, Jacobs JP, et al. Patient satisfaction with a teleradiology service in general practice. BMC Fam Pract. 2016; Feb 10; 17: 17. DOI: 10.1186/s12875-016-0418-y.

7. Морозов С. П., Владзимирский А. В., Сименюра С. С. Качество

первичных телемедицинских консультаций «пациент-врач» (по результатам тестирования телемедицинских сервисов). Врач и информационные технологии. 2020; 1: 52-62. DOI: 10.37690/1811-0193-2020-1-52-62.

8. Владзимирский А. В., Морозов С. П., Сименюра С. С. Телемедицина и COVID-19: оценка качества телемедицинских консультаций, инициированных пациентами с симптомами ОРВИ. Врач и информационные технологии. 2020; 2: 52-63. DOI: 10.37690/1811-0193-2020-2-52-63.

9. Суслин С. А., Вавилов А. В., Ганнатулина Р. И. Удовлетворенность пациентов городской многопрофильной больницы медицинским обслуживанием. Организация здравоохранения. 2018; 5 (4): 118-25. DOI: 10.17709/2409-2231-2018-5-4-12.

10. Касапов К. И., Некрасов А. Ю., Величко Е. А. Социологический опрос пациентов хирургического профиля как инструмент удовлетворенности оказываемой медицинской помощи. Вестник Смоленской государственной медицинской академии. 2017; 16 (4): 38-42.

11. Müller KI, Alstadhaug KB, Bekkelund SI, et al. Acceptability, feasibility, and cost of telemedicine for nonacute headaches: a randomized study comparing video and Traditional consultations. J Med Internet Res. 2016; 18: e140. DOI: 10.2196/jmir. 